\title{
An Assessment of Recent Market Performance of REITs in a Developing Economy
}

\author{
Stephen O. Aro-Gordon ${ }^{1}$, Abdullahi M. Bashir ${ }^{2}$,Dauda O. Abdulsalam ${ }^{3}$, and \\ Hussainatu Abdullahi ${ }^{4}$ \\ ${ }^{I}$ Department of Financial Mathematics, Baze University, Off Jabi-Airport Bypass (Ring Road), Abuja, Nigeria \\ ${ }^{2}$ Department of Accounting and Finance, Usmanu Danfodiyo University, PMB 2346, Sokoto, Nigeria \\ ${ }^{3}$ Department of Business Administration, Usmanu Danfodiyo University, PMB 2346, Sokoto, Nigeria \\ ${ }^{4}$ Department of Economics, Usmanu Danfodiyo University, PMB 2346, Sokoto, Nigeria
}

\begin{abstract}
The study appraised the recent performance of Real Estate Investment Trust (REIT) as a new investment vehicle in Nigeria. While REITs are often presented as useful tools for diversification, little is known about the variations in the empirical correlations between the country's REITs' returns and the general market index. The paper addresses this issue using published data over the first four trading years $(2008$ - 2011) of Skye Shelter Fund, the country's premier publicly traded REIT. Data inquiry schedules were developed to gather annual market and REIT'sreturndata based on the analytical framework provided by Capital Asset Pricing Model.Using regression analysis, the results of the study showed that the Nigerian REIT wasweaklycorrelated to the broad market during the 4-year period of the analysis. The findingssupport the importance of REITas a relatively low-risk, stableasset class that investors can leverage for building sustainable optimal portfolios, particularly during periods of heightened macroeconomic uncertainties of the kind witnessed during the 2008 global financial crisis. The significance of this research is the potential to chart the way forward by presenting investment opportunities in REITfor policy makers, international development institutions, financial organisations, and research centres.
\end{abstract}

Keywords:CAPM, Global Financial Crisis, Market Risk, Nigerian Economy, REITs

\section{Introduction}

One important fall-out of globalization is the increasing sophistication of capital markets accentuated by the introduction of new investment vehicles such as Real Estate Investment Trusts (REITs). REITs are businesses that invest, develop or operate income-producing landed properties ranging from residential houses, offices, to shopping complexes, event centres, malls, hotels, industrial buildings or warehouses, and whose shares are usually traded on stock exchanges. As a highly liquid method of investing in real estate, REITs provide returns to investors through capital appreciation from price changes and annual distributions from investment income such as rental proceeds or outright asset disposals from time to time. Since the US Congress passed the REIT Act in 1960 as a way to expand the traditional investment world beyond stocks and bonds, the investment universe of REITs has seen a phenomenal growth especially over the past twenty years. Nearly 70 percent of $\$ 1$ trillion global real estate equity market capitalisation of public real estate as of mid-2012 is believed to be constituted by REITs (FTSE, 2010; Goodchild, 2008).

Consequently, there is an increasing perception of the superior value of REITs, particularly as regards providing investors the means for portfolio diversification needed to generate stable income streams from their portfolios at low risk. So far, however, there has been little discussion about the empirical nature of Nigeria's REITs (N-REITs). The rather limited knowledge of dynamic nature of secondary property investment vehicles like REITs is believed to have contributed to the relatively low deployment of Nigeria's real estate capital market as a tool for strengthening the country's property finance and investment sector, and addressing the country's perennial N60 trillion housing finance deficit (Zyl, 2010; Moghalu, 2011).

It is against foregoing background that this study sought to appraise the recent investment performance of REITs in Nigeria. The pertinent question borders on the extent to which N-REITs are correlated with the stock market the answer to which would be helpful in determining the usefulness of the instrument in helping to diversify asset portfolio. As Lynn (2011) asks: Is real estate still a good diversifier? Using the country's flagship REIT (Skye Shelter Fund) as a proxy, the present study was therefore designed to determine the extent to which the N-REIT's rate of return is correlated with the broad market's rate of return, so as to establish the true portfolio-diversification worth of the new property-backed financial instrument in Nigeria.This paper is important because current findings are expected to, among otherimplications, expand the literature on investment analysis and portfolio management by providing fresh insight into evolving nature of N-REITs. Results from the study may therefore be valuable for equipping asset managers, institutions and organisations, 
with evidence-based insights into the emerging nature of N-REITs that could assist them to make robust investment decisions and policies in a random and uncertain business environment.

The paper is divided into five sections. The first section is this background information. In section two, relevant literatures were reviewed along with highlights of the development of REITs in Nigeria, while section three introduces the methodology of the study. Section four presents the research findings. The paper ends in section five with a summary of the study's conclusions/implications for corporate finance theory and policy.

\section{Literature Review}

The case for indirect investment in real estate through REITs is perhaps well-documented in the literature (Knight Frank Residential Research, 2006; Shermma \& Jeon, 2010; Souza, 2011; Oteh, 2011, Boudry, Coulson, Kellberg, \& Liu, 2012; Feug, Ghosh, \& Sirmans, 2013). Theoretically, REIT is a specialised propertybacked business model (high-yielding, with special tax benefits) that allows investment in tangible property without actively owning (Iyiegbuniwe, 2007; ISA, 2007). REITs are typically structured to provide a similar vehicle for investment in real estate as mutual funds provide for investment in stocks. Like other corporations, REITs can be publicly (that is listed in public exchanges) or privately held (Sanya, 2011; Adetunbi, 2006).

The importance of market risk in investment analysis is also well documented in the literature. The market risk principle states that every market participant is deemed exposed to the same vagaries of the macroeconomic environment in which businesses operate, and therefore, the reward for bearing risk depends only on the systematic risk of an investment, that is, the degree to which the asset's rate of return correlates with the market portfolio (Brealey, Myers, \& Allen, 2014; Ashamu, 2009; Graham \& Dodd, 2009; Blaaw, 2009). The business environment consists of a long list of such 'uncontrollable' factors - such several factors or conditions within (internalities) and outside (externalities) the business organization - that combine to exert pressure on a company's capacity to fulfill its business objectives. The "market portfolio" is used to refer to all the registered securities or listed businesses on a stock exchange, and thus a robust proxy for the macroeconomic environment (Olowe, 2011). Firms or industries are believed to respond differently to market risk. In this regard, Capital Asset Pricing Model (CAPM) is probably the most apt device by which the relationship between expected return of a security and its avoidable risk can be measured relative to the market portfolio (Iyiegbuniwe, 2007). In essence, CAPM posits that the expected risk premium on each stock is proportional to its beta - one of the best known measures of how sensitive the individual security is to the market movements. In essence, the CAPM theory collapses all externalities into a well-defined factor - stock market return, denoted, $R m$ (Brealey et al., 2014) Market return $(R m)$ is a derivate of market PER (Price-Earnings ratio), the aggregate PERs of all listed equities on the stock exchange.

\section{An Overview of the Nigerian Economy and Emergence of REITs}

Nigeria, a middle-income, mixed economy and emerging market, with an expanding financial services industry, is Africa's most populous nation and the leading oil and gas producer in the continent. From 2005 until 2013, driven largely by non-oil production activities including real estate, Nigeria Gross Domestic Product (GDP)(\$509.9 billion: 2013rebased estimate) growth rate averaged 6.8 percent reaching an all-time high of 8.6 percent in December of 2010 (The World Bank, 2014). Up from its ranking as $52^{\text {nd }}$ in 2000 , the country is now ranked $26^{\text {th }}$ in the world in terms of GDP purchasing power parity, and now (post-rebased GDP) Africa's biggest economy (National Bureau of Statistics [NBS], 2014). Pursuing her Vision 20: 2020 to become one of 20 largest economies in the world by 2020, Nigeria is 76 percent of ECOWAS (West African sub-regional economic body)economy, 30 percent of sub-Saharan Africa, and 21 percent of Africa's economy (OkonjoIweala, 2014; MINT countries, 2014; Adebowale, 2014).

Perhaps one of the reasons for including Nigeria among the MINT (Mexico, Indonesia, Nigeria, and Turkey) is the country's humongous opportunities reflected in the significant under-representation of commercial real estate in the country's stock market, yet the real estate sector remains a potentially key part of the economy (Baum, 2013). The country's real estate GDP rebased value of $\mathrm{N} 6.43$ trillion in 2013, growing steadily from 12.2 percent in 2011 to 16.4 percent in 2013, and its present level of contribution to the country's GDP at 8 percent, are indicative of the sector's huge economic potentialities (NBS, 2014). Nigerian REITs (NREITs) have only just emerged since 2008 following SEC's regulatory framework (Investment and Securities Act [ISA], 2007) and is beginning to witness some appreciable growth in the country's financial landscape. Partly encouraged by the Pensions Act (2004) which allows 40 percent of pension funds to be invested in REITs and mortgaged-backed securities, the country currently has three REITs with aggregate market capitalisation of US $\$ 0.5$ billion ( $\mathrm{N} 82$ billion), compared to the US REITs equity market capitalisation of $\$ 400$ billion, Japan's 35 REITs with $\$ 42$ billion market capitalisation, and Singapore's 26 REITs with $\$ 30.5$ billion(Ferri, 2012). After Skye Shelter Fund was introduced as the first REIT publicly listed on the Nigerian Stock Exchange on 26th February 2008, the market received further boost with $\mathrm{N} 50$ billion (US\$312.5 million) Union Homes Hybrid 
REIT launched in September 2008, while UPDC REIT, issued for $\mathrm{N} 30$ billion (US $\$ 187.5$ million) in FebruaryMarch 2013, entered the market as perhaps the country's latest publicly traded REIT (BGL Plc, 2013).

\section{Empirical Evidence}

While the weak correlation between large cap stocks and real estate equities has been observed in some more developed markets like the US (Appraisal Institute, 2001; Ferri, 2012), in the Nigerian context,comparable researches to date(notably, Amidu, Aluko, Nuhu, \& Saibu, 2008;Bamiduro\& Aro-Gordon, 2007; Amidu\& Aluko, 2006) have been rather focused on real estate operating companies and return performance than NREITs and their market risk behaviour, prompting the present work. This limitation from past efforts may however explained by the fact the N-REIT is a relatively new phenomenon in Nigeria.Further empirical evidence was deemed pivotal to complement earlier results that were only based on 3-year dataset (Aro-Gordon, 2013). Buttressing the relatively weak correlation of real estate asset class generally, Bello (2003) and Ojetunde (2013), among others, have shown that the Nigerian private property market is relatively slow in adjusting to the constantly changing macroeconomic events in Nigeria, but empirical awareness of the situation with publicly traded REITs remains largely sparse, leaving a knowledge gap (up-to-date empirical behaviour of the newproperty-backed financial instrument) which the present papertries to fill.

\section{The Methodology and Model}

Using asset return data sourced primarily from published materials and annual reports and accounts of Skye Shelter Fund (Skyeshelt) andtheNigerian Stock Exchange (NSE),descriptive and regression analytical techniques were deployedtoevaluate themarket performance of publicly traded REIT from 2008 to 2011. Specifically, the data sourced include the following variables: movements in the N-REIT's market prices, subject REIT's return $(R i)$ and market return $(\mathrm{Rm})$. The use of published historical data for this study accords with current thinking in capital market research (Seaman Jr \& Smith, 2012). The 4-year study period was justified by the need to reflect market developments following the 2008 global financial crises. Skyeshelt is Nigeria's first and longest publicly traded equity REIT and thus adopted in this paper as a reliable proxy for the empirical analysis. Descriptive, correlation and regression analytical techniques were deployed for the study. Quantitative analysis was facilitated by Microsoft Office Excel 2010 version. The research enquiry on N-REIT's market risk was achieved following the standard statistical approach of regression analysis (Freedman, 2005). In this respect, the study was guided by the following hypothesis:

Ho:There is no significant correlation between N-REIT stock's return and market portfolio return.

The Student's t-Test statistic was deployed following the standard procedure (Moti, 2005) at t 95 percent (0.05) confidence level, based on N-1 degree of freedom. The coefficient of determination, R-squared $\left(\mathrm{R}^{2}\right)$, was used to indicate the 'variability' of the empirical dataset, or the strength of the linear relationship between N-REIT's return and the market portfolio return. The application of $\mathrm{R}^{2}$ as a simple measure of goodness of fitis justified by its apt measurement of the total variance in REIT stock's returns that can be attributed to market movements (Brealey et al., 2014).

The $\mathrm{R}^{2}$ was computed as the square of the correlation between the outcomes and the values of the single regressor, that is,

$R^{2}=1-\frac{S S_{R e s}}{s S_{\text {tot }}}$

Where,

$S S_{\text {Res }}=$ Residual sum of squares

$S S_{\text {tot }}=$ Explained total sum of squares

The values of $\mathrm{R}^{2}$ test ranges between 0 and 1 ; the higher the correlation between the returns being analysed, the closer the $\mathrm{R}^{2}$ is to " 1 ".

TheCAPM's beta coefficient was used to determine whether or not there is any significant correlation between N-REIT's return and market return during study period. Despite the model's flaws, as observed by Fama and French (2004), among others, CAPM is widely used in the literature (Amidu et al. 2008; Ashamu, 2009; Olowe, 2011, Brealey et al., 2014) and was used in the present appraisal due to its simplicity and utility, especially given the nascent nature of N-REIT market. The CAPM collapses all externalities (such as random changes in political, economic, social, and technological environment) into a well-defined variable - market return. Beta coefficient $(\beta i)$ of N-REIT stock $(\beta i)$ is given by the formula:

$\beta i=\frac{\text { Covariancewit hthemarket }}{\text { Variancewit hthemarket }}=\frac{\text { oim }}{\sigma^{2} R m}$

That is, 
$\beta i=\frac{\frac{1}{N-1} \sum(R i-\overline{R i})(R m-\overline{R M})}{\delta^{2}(R m)}$

Where,

$R i \quad=$ N-REIT's nominal rate of return of real estate stock $\mathrm{i}$

$R m \quad$ = Market rate of return

$N \quad=$ Number of observations

$\overline{\boldsymbol{R i}} \quad=$ Average nominal rate of return of real estate stock $\mathrm{i}$

$\overline{\boldsymbol{R} \boldsymbol{m}}=$ Average market rate of return

$\operatorname{Cov}(R i, R m)=$ Covariance of return on N-REIT with the returns on a market portfolio

The market return $(R m)$ was determined as a derivative of market PER (Price-Earnings Ratio) over the study period, as follows:

$\boldsymbol{R m}=\frac{1}{\text { MarketPER }}$

PER is given by the reversal of equation (3) as applicable to the N-REIT or the market portfolio.

\section{Findings and discussions}

One of the most important findings to emerge from this study was that N-REIT has so far generally exhibited no significant correlation with the market portfolio, consistent with current thinking (Appraisal Institute, 2001; Sanya, 2011). Table 1 highlights the return performance of N-REIT and the market portfolio for the period 2008 - 2011. Interestingly, at a time when the broad market witnessed a general decline in 2010 with $R m$ at 7.02 percent, N-REIT's rate of return ( $R i$ ) recorded a high of 12.11 percent in the same year. Table 2 suggests that the REIT asset class is a type of capital asset that has a tendency to be minimally impacted by externalities in the long-run.

Table 1: Return performance of N-REIT and the market portfolio, 2008- 2011

\begin{tabular}{|l|l|l|l|l|}
\hline Data/Results & $\mathbf{2 0 0 8}$ & $\mathbf{2 0 0 9}$ & $\mathbf{2 0 1 0}$ & $\mathbf{2 0 1 1}$ \\
\hline REIT's End-December market price Naira $(P)$ & 111.10 & 100.00 & 97.00 & 100.00 \\
\hline REIT's earnings per unit $(E P U)$ Naira & 5.73 & 8.73 & 11.75 & 4.48 \\
\hline REIT's earnings' yield, $R i(\%)$ & 5.16 & 8.73 & 12.11 & 4.48 \\
\hline Market Price-Earnings Ratio (PER) & 15.94 & 11.46 & 14.24 & 14.32 \\
\hline Market Return (\%) Rm on the NSE & 6.27 & 8.73 & 7.02 & 6.98 \\
\hline Nigerian Treasury Bill Rate, $R f(\%)$ & 4.50 & 6.05 & 7.50 & 14.00 \\
\hline
\end{tabular}

Sources: Authors' research, NSE (2012), and computation results, 2013.

Figure 1 highlights the weak correlation of real estate stocks relative to the broader market: While the mainstream market curve appeared somewhat flat, the N-REIT curve appeared conical with a sharp fall to 4.48 percent yield in 2011 from its height of 12.11 percent in 2010. The result aligns with past findings on the general uncorrelated nature of real estate securities, thus revalidating the portfolio risk-diversification value of REITs (Boudry et al., 2012; Goodchild, 2008; Sanya, 2011)

Figure 1: Weak correlation: The $R m$ and $R i(N-R E I T)$ curves, $2008-2011$.

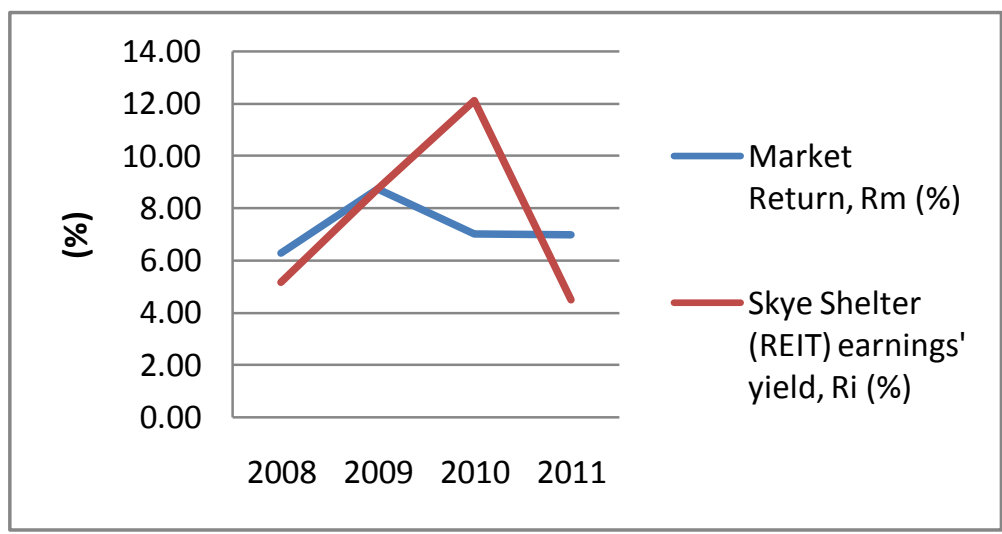

Sources: Authors' research and computations, 2013

Table 2 highlights beta coefficient and $R^{2}$ matrix of the N-REIT over the period from 2008 to 2011. It was observed that the calculated t value of 0.5 was less than the t-table value $(=2.13)$ at 0.05 significance level, 
while the $\mathrm{R}^{2}$ value $(0.122)$ was also far below the 0.70 threshold. In other words, Skyeshelt's beta $>1$ indicates that the N-REIT is not perfectly correlated with the market; it might tend to swing in the same direction but it would rise or fall probably more than thrice more than the general market.

Table 2: Beta coefficient and $R^{2}$ matrix of N-REIT (2008- 2011)

\begin{tabular}{|l|l|l|l|l|}
\hline N-REIT & $\boldsymbol{\beta}$ & t-Test & $\begin{array}{l}\text { Critical Value } \\
\text { significance level }\end{array}$ & $\mathbf{R}^{\mathbf{2}}$ \\
\hline Skye Shelter Fund & 3.54 & 0.5 & 2.13 & 0.122 \\
\hline
\end{tabular}

Sources: Authors' research and computation results, 2013

There are several possible explanations for REITs' weak correlation with the general market. First of all, Man's need for land and shelter is constant, regardless of the market or economic season. The tendency for rental housing to be particularly recession-resistant, funding and construction lags typical of the property supply or development industry, REITs' exposure to a diversified property portfolio of income-generating assets across major geographical markets and property types, and strong rental cash flow have also been cited (Appraisal Institute, 2001; Carricko, 2008; Oteh, 2011). In essence, the current finding aligns with the current thinking in the field and particularly reinforces the high portfolio-risk diversification value of N-REIT's as a veritable investment vehicle in a developing economy (BGL, 2011; Sanya, 2011; Baum, 2013).

\section{Conclusion}

The paper provides further evidence of the portfolio-risk diversification nature of REITs in the Nigerian context in consistency with the growing body of literature in the field. This study has shown that NREITs remain largely noncyclical, low-risk, good risk-diversifiers that investors can leverage for building stable, optimal portfolios, particularly during periods of heightened macroeconomic uncertainties of the kind witnessed over the recent years across the world. This has positive implications for corporate finance practice, in terms of helping to establish REIT as a valuable asset class for sustainable national development through optimal portfolio performance, stability, and growth.

Two caveats need to be noted regarding the present contribution. Firstly, the sample size for this study is small, but this is because of the relative infancy of the N-REITs. Consequently, caution must be applied, as the findings may not be transferrable to some other variants of REITs, such as privately held REITs. Secondly, the CAPM and the simple R-squared tool used in this paper on their own do not tell us the entire story; further research may be necessary to incorporate other approaches such as Fama-French three-factor model, and to use daily or monthly returns rather than annual dataset, so as to compliment the evidence database provided in this paper.

\section{References}

[1]. Adebowale, Y. (2014, April 5). It's official tomorrow: Nigeria's economy, Africa's biggest. Thisday (Nigeria), p. 1.

[2]. Adetunbi, S. (2006, December 16). Real estate investment trust - Nigerian structure in view. Unpublished presentation obtainable from seye@valueinvesting.com.

[3]. Amidu, A., Aluko, B. T., Nuhu, M. B., \& Saibu, M. O. (2008). Real estate security and other investment assets: A comparison of investment characteristics in the Nigerian stock market. Journal of Property Investment and Finance, 26, (2), 151-61.

[4]. Amidu, A., \& Aluko, B. T. (2006, May - August).Performance analysis of listed construction and real estate companies in Nigeria.Journal of Real Estate Portfolio Management, 12, (2), 177-85.

[5]. Appraisal Institute (2001). The appraisal of real estate. $12^{\text {th }}$ ed. Chicago: Appraisal Institute.

[6]. Aro-Gordon, S. O. (2013). A study of the behaviour of real estate stock prices in the Nigerian capital market. PhD Thesis, Faculty of Management Sciences, Usmanu Danfodiyo University, Sokoto, Nigeria

[7]. Ashamu, S.O. (2009), financial investment and management analysis. Lagos: Molofin Nominees.

[8]. Bamiduro, J. A., \& Aro-Gordon, S. O. (2007). Real estate-backed securitization as a veritable strategy for capital market development: An assessment of the UPDC Model. Babcock Journal of Management and Social Sciences, January Special Edition, (5), 2, 83-100.

[9]. Baum, A. (2013) at a roundtable on "Catalyzing the growth of REITs in Nigeria." Retrieved February 26, 2013 from www.vanguardngr.com/2013/02/reits-w... Professor Andrew Baum of Cambridge University, Britain, estimates the gross value of real estate in Africa is only one percent of the world's total value despite the fact that the continent controls 15 percent of world population.

[10]. Bello, O. M. (2003). Comparative analysis of the performance of residential property investment and investment in securities in Lagos, Nigeria.The Estate Surveyor and Valuer, 26, (1), $7-14$.

[11]. BGL Plc (2013, February 24). Equity note: UPDC REIT initial public offer. Thisday, pp. 34 - 35.

[12]. BGL Plc (2011, December 11). The Nigerian real estate industry: The need for critical solutions to perennial housing challeng es. Thisday, pp. $30-33$.

[13]. Blaaw, A. J. (2009, August 3). Market risk management in Nigeria.Thisday, 14 (5216), p. 53

[14]. Boudry, W., Coulson, N. E., Kallberg, J. G., \& Liu, C. H. (2012). On the hybrid nature of REITs.Journal of Real Estate Finance and Economics, 44 (1/2). Social Science Electronic Publishing, Inc, Retrieved on 26 ${ }^{\text {th }}$ May 2013, from http://ssrn.com/abstract=1991372.

[15]. Brealey, R.A., Myers, S.C., \& Allen, F. (2014).Principles of corporate finance, $11^{\text {th }}$ edn. London: McGraw-Hill.

[16]. Carricko, R. (2008, December 6). REITs battered down to eye-catching levels. The Globe \& Mail.Retrieved on May, 24, 2013, from www.reportonbusiness.com 
[17]. Fama, EF, \& French, KR (2004).The capital asset pricing model: Theory and evidence. .Journal of Economic Perspectives, (18), 3, $25-46$.

[18]. Ferri, R. (2012). The total economy portfolio. Retrieved 30 November 2013 from http://www.forbes.com/../2

[19]. FTSE (2010).FTSE EPRA/NAREIT Global real estate index series. Retrieved 2 December from http://www.ftse.com/indices/

[20]. Feug, Z., Ghosh, C., \& Sirmans, C. F. (2013).On the capital structure of REITs. Retrieved on June 3, 2013, from http://www.landecon.cam.ac.uk/research/reaug/maastricht/pdf/Feng\%20Ghosh\%20Sirman.pdf.

[21]. Freedman, D. A. (2005).Statistical models: Theory and practice.Cambridge University Press.

[22]. Graham, B, \& Dodd, D (2009). Security analysis.New York: McGraw-Hill

[23]. Goodchild, B. (2008). REITs - A global phenomenon. Journal of Property Investment and Finance, 26 (3): 195 - 209.

[24]. Investment and Securities Act [ISA]. (2007): Lagos: the Federal Government Printer.

[25]. Iyiegbuniwe, W.C. (2007). The essence of finance: Maximizing life-time happiness. University of Lagos. Retrieved on May 11, 2010, from http://www.unilag.edu.ng/publication/ope...

[26]. Knight Frank Residential Research [KFRR] (2006).The case for indirect investment in residential property. Retrieved on June 30, 2009, from http://www.resources.knightfrank.com/getresearchreource.ashx.id=10830

[27]. Lynn, D. (2011, August 1). Is real estate still a good diversifier? National Real Estate Investor.Retrieved on January 13, 2013, from http://www.nreaionline.com

[28]. MINT Countries. (2014). Wikipedia. Retrieved 19 January 2014, from http://en.wikipedia.org/wiki/MINT countries

[29]. Moghalu, K. (2011, August 12). In "FG needs N60 tn to address housing deficit", The Punch, p. 19.

[30]. National Bureau of Statistics (NBS) (2014). Measuring better: Presentation of preliminary results of the rebased nominal Gross Domestic Product (GDP) estimates for Nigeria, 2010 - 2013, delivered by the Statistician General of the Federation and CEO, National Bureau of Statistics, Dr. Yemi Kale, Transcorp Hilton Hotel, Abuja on $6^{\text {th }}$ April, 2014. Retrieved on $15^{\text {th }}$ April 2014 from http://www.nigerianstat.gov.ng

[31]. Ojetunde, I. (2013). Revisiting the interaction between the Nigerian residential property market and the macro-economy. Presentation at the International Federation of Surveyors Working Week held in Abuja, 6 - 10 May, 2013, Retrieved on June 3, 2013, from http://www.fig.net/pub/monthly-articles/may

[32]. Okonjo-Iweala, N. (2014, May 6). In 1000 delegates from 70 countries to storm Abuja.The Punch, p. 30.

[33]. Olowe, R. A (2011). Financial management: Concepts, financial system, and business finance. $3^{\text {rd }}$ ed. Lagos: Brierly Jones Nigeria Limited.

[34]. Oteh, A. (2011). The role of the real estate in capital market development. An Opening Speech at the Nigerian Institution of Estate Surveyors and Valuers (NIESV) Seminar and Fellows Night on January $28^{\text {th }} 2011$,www.sec.gov.ng [retrieved on $16^{\text {th }}$ December 2011].

[35]. Sanya, O. A. (2011). Real estate investment trust: A veritable tool for housing development in an emerging market. Presentation at the International Housing Finance Workshop organized by Pison Housing Company, held in Lagos on 8-10 August, 2011, obtainable frominfo@gma.com.ng

[36]. Seaman Jr, J. T., \& Smith, G. D. (2012).Your company's history as a leadership tool.Harvard Business Review. (December), pp. 45 -52 .

[37]. Securities and Exchange Commission [SEC] (2013, February 28). In new rules/amendments to the rules and regulations of the SEC. Abuja: SEC

[38]. Souza, L. A. (2011). Modern real estate portfolio management: Applications to western regional apartment portfolios. A Paper on Corporate Finance, Golden Gate University, San Francisco, CA. Retrieved from Lsouza@johnsonsouzagroup.com.

[39]. The Nigerian Stock Exchange (NSE) (2012), 2011/12 Fact Book, Lagos,NSE, ISBN 9780262 - 1 - 6. [Additional data contributions received from Mr. Adeyemi Osoba (Deputy Editor, NSE Fact Book, e-mail: aosoba@nigerianstockexchange.com) on market Price-Earnings Ratios and dividend yields are gratefully acknowledged].

[40]. The World Bank (2014).Data. Retrieved 7 January 2014, from http://data.worldbank.org/

[41]. Zyl, J. (2010). Financing retail commercial development in Nigeria: Options and challenges. MBA Thesis,The Graduate School of Business, University of Cape Town, South Africa. 